\title{
Characterization of Brazilian Northeastern plastic clays
}

\section{(Caracterização de argilas plásticas do Nordeste brasileiro)}

\author{
A. Laursen ${ }^{1 *}$, L. N.L.Santana ${ }^{1}$, R. R. Menezes ${ }^{1}$ \\ ${ }^{1}$ Federal University of Campina Grande, Department of Materials Engineering, \\ Laboratory of Materials Technology, 58429-900, Campina Grande, PB, Brazil
}

\begin{abstract}
Plastic clays are one of the main raw materials used in ceramic technology. However, there is a shortage of good quality plastic clays in the world for use in porcelain technology. The aim of this study was to characterize plastic clays from Northeastern Brazil. Chemical and mineralogical composition, particle size distribution, plasticity and green strength of the clays were determined. The analyzed clays were predominantly composed of kaolinite and quartz, and some contained smectite. The amount of iron oxide in the clays was higher than $1.0 \%$ and for some of them the values were higher than $3 \%$; the liquid and plastic limits ranged from $22 \%$ to $48 \%$ and $10 \%$ to $32 \%$, respectively. According to characterization data, three plastic clays had potential to be used as alternative ball clay, due to their plasticity and mineralogical characteristics.
\end{abstract}

Keywords: plastic clay, characterization, porcelain, sanitary ware.

\section{Resumo}

Argilas plásticas são uma das principais matérias-primas usadas em tecnologia cerâmica. No entanto, há uma escassez dessas argilas no mundo para o uso em tecnologia de porcelanas. O objetivo deste trabalho foi caracterizar argilas plásticas do nordeste brasileiro. Composições química e mineralógica, distribuição do tamanho de partículas, plasticidade e resistência à verde dessas argilas foram determinadas. As argilas analisadas foram constituídas predominantemente por caulinita e quartzo e algumas contiveram esmectita. A quantidade de óxido de ferro nessas argilas foi maior que 1,0\% e em algumas alcançou valores superiores a 3\%; os limites de liquidez e plasticidade variaram de 22\% a 48\% e 10\% a 32\%, respectivamente. De acordo com os dados de caracterização, três argilas plásticas apresentaram potencial para serem usadas como 'ball clay' alternativa de acordo com a plasticidade e características mineralógicas.

Palavras-chave: argila plástica, caracterização, porcelana, louças sanitárias.

\section{INTRODUCTION}

The production of porcelain bodies such as sanitary products is a significant and important sector of the ceramic industry. The quality of these ceramics depends on processing conditions, but especially on the raw materials. Studies have emphasized the influence of raw materials on the microstructure of porcelain ceramics [1-5]. However, the development of formulations for these ceramics using natural raw materials is still a complex challenge due to the diversity of clays' characteristics [1], mainly those of plastic clays, known as ball clays, used in porcelain technology.

The term ball clay is used to describe fine-grained, highly plastic, sedimentary kaolinitic clays [6]. These clays can also be defined as kaolinitic clay with minor to abundant organic matter content which generates high green strength as well as fired strength in ceramic bodies and usually results in fired product with white or off-white color [7-11]. Ball clays also have a profound influence on the rheological properties

*andersonlaursen@yahoo.com.br

Dhttps://orcid.org/0000-0002-9941-905X of the dispersions used in the production of sanitary ware porcelains [2]. Sanitary products are molded by slip casting process and the viscosity must be adequate for the dispersion be easily poured into the mold. The chemical and mineralogical characteristics of the used ball clays greatly determine the suspension's rheological behavior [1].

However, despite the importance of these plastic clays, there are no large deposits of ball clays in Brazil and South America. The most used ball clay in Brazil is from a deposit in the State of São Paulo, Brazil, called São Simão. However, these mineral reserves nowadays are depleting and yielding low-quality material, which is causing great concern to the productive sector. This extremely worrying scenario is stimulating the search for alternative sources of raw materials to supply the Brazilian industry in coming years. The importance and difficulty in finding high-quality plastic clays that can be used as ball clays have prompted several studies worldwide [8-10, 12-17] aiming at the discovery of new deposits or finding alternative plastic clays that can replace ball clays in their applications. Therefore, the aim of this study is to characterize plastic clays from Northeastern Brazil. 


\section{EXPERIMENTAL PROCEDURES}

Materials: six clays from the city of Oeiras, State of Piauí, Northeast of Brazil, were characterized in this study. The clays were named as EC (Elias Costa), LB (Lambedor), MC (Mucambinho), SR (Santa Rita), and ST (Sítio). A traditional ball clay from Brazil, São Simão (SS) clay, was used as a reference sample. The clays were sieved with a 200 mesh $(0.074 \mathrm{~mm})$ sieve and characterized.

Methodology: the clays were characterized by X-ray fluorescence spectroscopy (XRF) and X-ray diffraction (XRD), loss on ignition (LOI), differential thermal analysis (DTA), thermogravimetry (TG), particle size analysis and Atterberg limits. XRF was performed with a Shimadzu EDX 720 apparatus, and XRD with a Shimadzu XRD 6000 apparatus operating with $\mathrm{CuK} \alpha$ radiation $(40 \mathrm{kV} / 30 \mathrm{~mA})$, reading time of $0.6 \mathrm{~s}$, step size of $0.02^{\circ}$, and scanning from $5^{\circ}$ to $60^{\circ}$ (crystalline phase quantification was performed using the internal standard method, using the $\mathrm{I} / \mathrm{I}_{\text {cor }}$ present in Joint Committee on Powder Diffraction Standards JCPDS files, and the calculus was performed by the software Shimadzu Search Match). LOI was determined after drying the sample at $110{ }^{\circ} \mathrm{C}$ for $24 \mathrm{~h}$ and firing at $1000{ }^{\circ} \mathrm{C}$. DTA and TG were performed on a Shimadzu $60 \mathrm{H}$ equipment. Particle size analysis was done by laser diffraction with a Cilas 1064 LD equipment and the Atterberg limits were determined according to ABNT NBR 6459 and NBR 7180 standards. After characterization, clays bodies $(60 \times 20 \times 5$ $\mathrm{mm}$ ) with several water contents were produced by uniaxial pressing at $20 \mathrm{MPa}$ in a Servitech CT-335 press. The bending modulus of rupture (MOR) of the samples thus prepared were determined by three-point bending test in a Shimadzu Autograph AG-X apparatus operating with a loading rate of $0.5 \mathrm{~mm} / \mathrm{min}$.

\section{RESULTS AND DISCUSSION}

Table I shows the chemical compositions of the clays investigated. Their LOI varied between $7.3 \%$ and $14.7 \%$. LOI reflects the mass loss during firing due to dehydroxylation of clay minerals and elimination of organic matter. Ball clays usually have a high percentage of organic matter that can be colloidal, non-colloidal or both [18-20]. Organic matter favors the stabilization of slip [21] and is important to provide green body strength. The LOI of SR clay was closest to that of the SS clay, while all other clays displayed lower LOI values, which may indicate a lower amount of clay material or organic matter in these clays. It is important to determine the iron oxide $\left(\mathrm{Fe}_{2} \mathrm{O}_{3}\right)$ content of porcelain ceramics because amounts higher than $3 \%$ not only lead to a dark tonality after sintering but also can decrease firing temperature. The decreasing of firing temperature is associated with the development of a large amount of liquid-phase during firing. This lower firing temperature is detrimental to the development of a higher fraction of mullite. In addition, when large percentages of iron oxide are present in ceramic formulations, a greater amount of enamel is required. Among the clays investigated, MC clay had iron oxide content higher than $3 \%$ while EC and SR clays had iron oxide amounts within the accepted limit. The amounts of silica and alumina in SR clay were closest to the reference clay (SS). The amount of $\mathrm{Al}_{2} \mathrm{O}_{3}$ present in clays mostly comes from the clay minerals and as such it is an indication of the content of clay minerals present in the material. A comparison of the chemical compositions of the clays investigated with those of Ukrainian ball clays [10] indicated that, despite the lower amount of $\mathrm{Al}_{2} \mathrm{O}_{3}$, the chemical composition of the LB clay was close to those of Ukrainian ball clays. $\mathrm{CaO}$ and $\mathrm{K}_{2} \mathrm{O}$ contents of the samples analyzed were higher than that of the SS reference sample. These oxides increase flow during molding procedures due to the presence of contaminants or accessory minerals in the plastic clays. The silica contents of the analyzed clays were also higher than that of the reference sample, except for samples MC and SR, which can indicate a higher amount of quartz in the clays or presence of 2:1 clay minerals in these clays.

Fig. 1 shows X-ray diffraction patterns of the clays investigated. All clays had kaolinite (JCPDS 78-2110), quartz (JCPDS 46-1045) and a small content of mica or illite (JCPDS 83-1808), except for the EC and SR clays that also had smectite clay mineral (JCPDS 13-0135) in their compositions. Table II presents the mineralogical composition of the studied clays. The mineral content

Table I - Chemical composition (wt\%) of the studied clays.

[Tabela I - Composição química (\% em massa) das argilas estudadas.]

\begin{tabular}{cccccccccccc}
\hline Clays & $\mathrm{SiO}_{2}$ & $\mathrm{Al}_{2} \mathrm{O}_{3}$ & $\mathrm{Fe}_{2} \mathrm{O}_{3}$ & $\mathrm{CaO}$ & $\mathrm{MgO}$ & $\mathrm{Na}_{2} \mathrm{O}$ & $\mathrm{K}_{2} \mathrm{O}$ & $\mathrm{TiO}_{2}$ & $\mathrm{BaO}$ & LOI $^{\mathrm{a}}$ & Others \\
\hline $\mathrm{EC}$ & 50.8 & 27.3 & 3.2 & 0.7 & 2.6 & 0.0 & 4.7 & 1.0 & 0.5 & 8.8 & 0.6 \\
$\mathrm{LB}$ & 60.6 & 25.5 & 1.4 & 0.0 & 1.2 & 0.0 & 2.2 & 0.7 & 0.2 & 8.1 & 0.1 \\
$\mathrm{MC}$ & 50.5 & 28.6 & 6.2 & 0.0 & 1.3 & 0.0 & 3.4 & 0.9 & 0.3 & 8.6 & 0.3 \\
$\mathrm{SR}$ & 48.8 & 32.8 & 3.0 & 0.3 & 1.1 & 0.0 & 1.4 & 0.2 & 0.6 & 11.6 & 0.2 \\
$\mathrm{SS}$ & 48.1 & 35.3 & 0.7 & 0.0 & 0.3 & 0.0 & 0.0 & 0.5 & 0.3 & 14.7 & 0.0 \\
$\mathrm{ST}$ & 64.7 & 23.7 & 1.1 & 0.1 & 0.8 & 0.0 & 1.5 & 0.8 & 0.0 & 7.3 & 0.0 \\
\hline a-loss on ignition. & & & & & & & & & &
\end{tabular}


ranged from $35 \%$ to $80 \%$ of kaolinite, $13 \%$ to $65 \%$ of quartz and $1 \%$ to $17 \%$ of illite. The compositions of the studied alternative clays were within the range of literature data for ball clays compositions, because ball clays have a wide range of mineralogical composition, $20 \%$ to $80 \%$ of kaolinite, $5 \%$ to $60 \%$ of quartz and $0 \%$ to $40 \%$ of illite [6, $9,10,16,18]$. Sometimes, smectite or illite/smectite (I/S) mixed-layered minerals also occur in ball clays [9], that can reach 25\% [19]. EC and SR clays presented a high and a low amount of smectite clay mineral, montmorillonite, of $28 \%$ and 3\%, respectively. Thus, SR sample was a kaolinitic clay with a small amount of smectite clay mineral, but the EC clay had a high amount of smectite. The smectite content strongly affects the rheological behavior of the clay dispersion. Smectite clay minerals have particle sizes lower than kaolinitic clay minerals, and when present or added to a dispersion they greatly increase the surface area of the solid material. Moreover, the small particles of smectite tend to agglomerate and, consequently, lead to the formation of intragranular pores. The high surface area and amount of small pores increase the water required for the dispersion, and thus, the presence of smectite clay minerals significantly increases the viscosity and the water/solid ratio necessary for the dispersion. Smectite clay mineral can also lead to dispersions with thixotropic behavior, which is not desirable during part manufacture since they may cause pumping complications and production of bodies with defects. Therefore although in the absence of good quality ball clay, small smectite contents may even contribute to stabilizing the system with the formation of face-to-edge structures, increasing the viscosity and decreasing the sedimentation rate of the material; however, the amount of smectite cannot be too high or it can compromise the productive process. $\mathrm{X}$-ray diffraction results were in agreement with chemical compositions (Table I), and it can be inferred that $\mathrm{MgO}$ and $\mathrm{Fe}_{2} \mathrm{O}_{3}$ contents detected in the clays were associated with mica and smectite present in the samples.

DTA and TG curves of the studied clays are shown in Fig. 2. Table III summarizes the loss of mass events. All samples displayed the following peaks in DTA curves: endothermic peak at approximately $110{ }^{\circ} \mathrm{C}$ associated to evaporation of free water in the samples; endothermic peak at approximately $580{ }^{\circ} \mathrm{C}$ related to dehydroxylation of clay minerals and formation of metakaolinite [12]; and exothermic peak at around $980{ }^{\circ} \mathrm{C}$ associated to formation of mullite. The SS clay presented an exothermic band that began at approximately $230{ }^{\circ} \mathrm{C}$ associated with the burning of its organic matter. Organic matter in the form of leaf imprints and disseminated lignite are common in most ball clays. Organic material in a clay affects the color and other properties and is advantageous in ball clays [6] because it can improve green/dry strength and rheological properties if in a very fine or colloidal form. However, except for the SS clay, no other sample displayed a similar exothermic band. The total loss of mass of the samples (Fig. 2b) ranged from $7.0 \%$ (ST) up to $14.6 \%$ (SS), and these were due to loss of water, hydroxyls and organic matter. The values of loss of

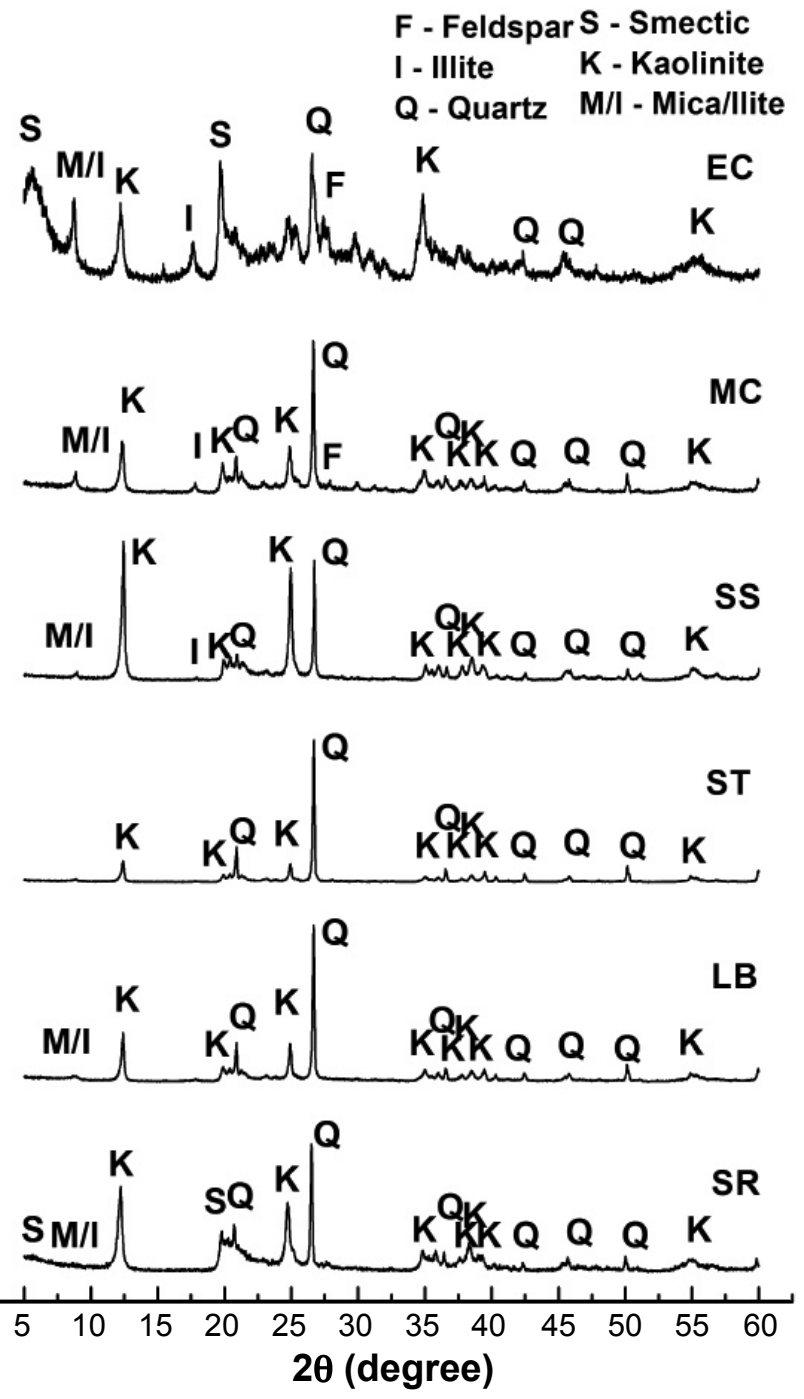

Figure 1: X-ray diffraction patterns of studied clays. [Figura 1: Difratogramas de raios $X$ das argilas.]

Table II - Mineralogical composition (\%) of the studied clays.

[Tabela II - Composição mineralógica (\%) das argilas estudadas.]

\begin{tabular}{ccccc}
\hline Clay & Kaolinite & Smectite & Quartz & Mica/Illite \\
\hline EC & 42.2 & 28.1 & 13.1 & 16.7 \\
LB & 48.6 & - & 51.4 & 2.0 \\
MC & 47.2 & - & 44.8 & 8.1 \\
SR & 62.5 & 2.5 & 33.5 & 1.5 \\
SS & 80.1 & - & 19.1 & 1.2 \\
ST & 35.0 & - & 65.0 & - \\
\hline
\end{tabular}

mass were in agreement with literature for plastic clays used as ball clays $[9,12,22]$. The SS sample had the highest loss of mass from 200 to $400{ }^{\circ} \mathrm{C}$ followed by the SR sample, which indicated that these samples contained the highest amounts of organic matter. Although MC and EC clays had intermediate values of loss of mass between 200 to $400{ }^{\circ} \mathrm{C}$, 
MC had a high iron oxide content in its composition while the XRD indicated that the EC clay had a high amount of smectite clay mineral.

Fig. 3 shows the particle size distribution curves of the clays investigated. The highest percentages of the particles
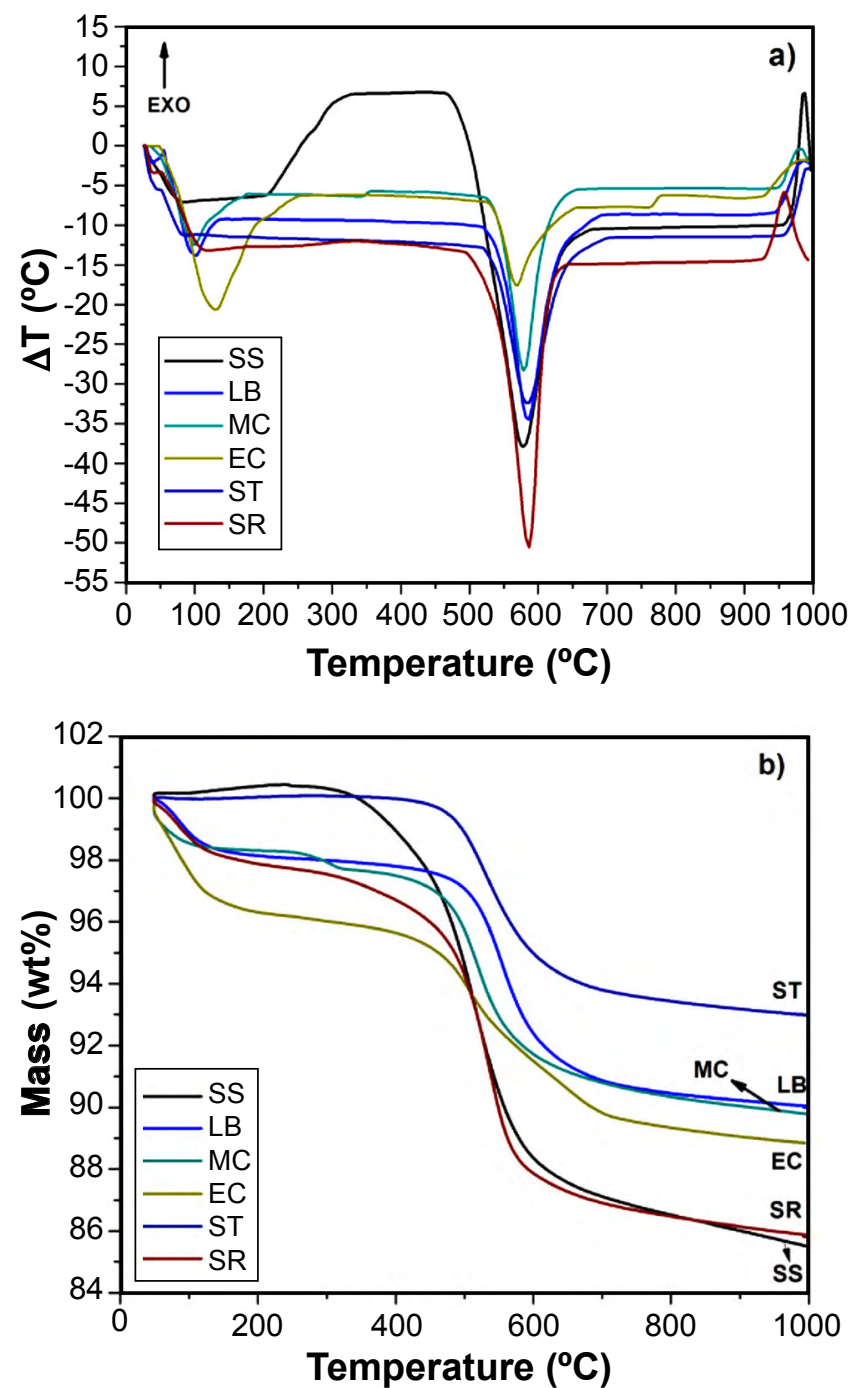

Figure 2: Thermal analysis curves of the clays investigated: a) DTA; and b) TG.

[Figura 2: Curvas de análises térmicas das argilas: a) ATD; $e$ b) $T G$.

Table III - Mass losses (wt\%) of studied clays.

[Tabela III - Perdas de massa (\% em massa) das argilas.]

\begin{tabular}{ccccc}
\hline Clay & $\begin{array}{c}0 \text { to } \\
200{ }^{\circ} \mathrm{C}\end{array}$ & $\begin{array}{c}200 \text { to } \\
400{ }^{\circ} \mathrm{C}\end{array}$ & $\begin{array}{c}400 \text { to } \\
1000^{\circ} \mathrm{C}\end{array}$ & $\begin{array}{c}\text { Total } \\
\text { loss }\end{array}$ \\
\hline EC & 3.7 & 0.7 & 6.8 & 11.2 \\
LB & 0.9 & 0.4 & 8.7 & 10.0 \\
MC & 0.7 & 0.8 & 8.7 & 10.2 \\
SR & 0.0 & 1.2 & 13.0 & 14.2 \\
SS & 2.3 & 1.4 & 10.9 & 14.6 \\
ST & 0.0 & 0.1 & 6.9 & 7.0 \\
\hline
\end{tabular}

with an equivalent diameter lower than $2 \mu \mathrm{m}, 57.8 \%$ and $40.5 \%$, respectively, were found in LB and ST clays while that of the reference SS clay was $38.8 \%$. Plastic materials used in the manufacturing of white ceramics need to have high amount of fine particles because they are responsible for the good finishing, favor sintering kinetics and the development of mullite [23]. Moreover, the green/dry strength of ball clays is closely related to particle size. In general, clays with finer particles have a higher green/dry strength. The clay samples presented equivalent average diameters ranging from 2.3 up to $5.8 \mu \mathrm{m}$. The SS sample had an average diameter of $5.7 \mu \mathrm{m}$. A study [24] on the use of Brazilian ball clays for the development of a mass for the production of sanitary ware porcelains indicated that these clays had an average diameter of $5.8 \mu \mathrm{m}$, which indicated that the obtained values for the clays investigated here were consistent with literature studies.

Table IV shows the plasticity characteristics of the clays under investigation. Plasticity is defined as the property of a material which permits it to be deformed under stress without rupturing and to retain the shape produced after the stress is removed [25]. However, the measurement of
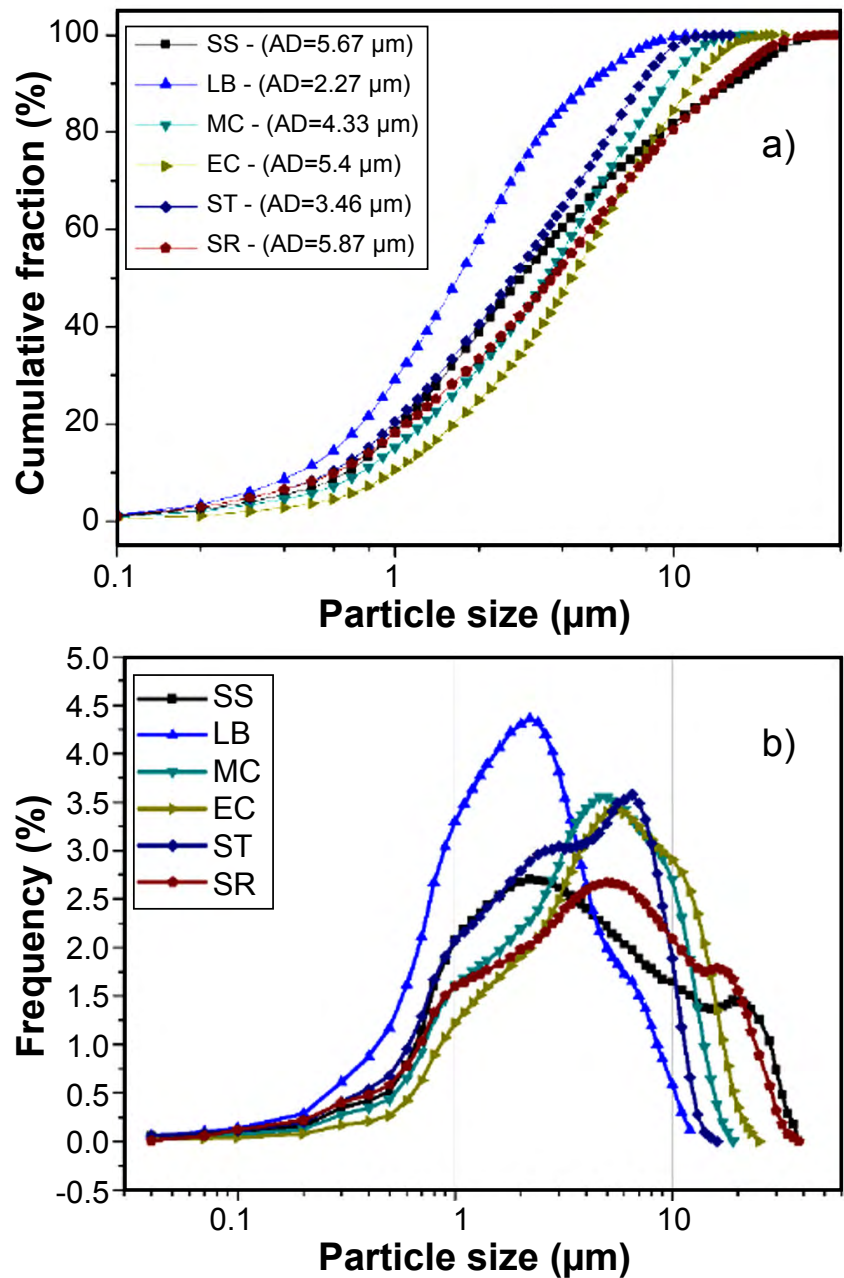

Figure 3: Particle size distribution curves of the clays.

[Figura 3: Curvas de distribuição de tamanho de partículas das argilas.] 
plasticity is difficult to determine quantitatively. One way to measure plasticity is by determining the amount or the range of water content required to develop plasticity. The lowest value of this range is called plastic limit and the highest value is called the liquid limit, and the amount of water in this range is the plasticity index. The reference sample (SS) showed a plastic limit that is characteristic of very plastic clay, and high liquid limit, which indicated the presence of high content of fine particles and/or organic matter. SR, LB and $\mathrm{MC}$ samples had plastic limits similar to those shown by the SS sample. This was in agreement with the observed values of loss of mass in the $200-400{ }^{\circ} \mathrm{C}$ range and the fineness data of the materials. The plasticity index of the SR and LB clays were similar to that of SS, while the value of the MC sample was higher. Researchers [26-28] point out that clay plasticity depends on its surface area, particle size distribution, and mineralogical composition. Thus, the lowest plasticity index value presented by ST sample can be associated to its high quartz content, while the highest value presented by EC sample can be associated to the presence of high amount of smectite clay mineral in this sample. The liquid limit, which is also important in a slip casting process, indicated that $\mathrm{LB}, \mathrm{MC}, \mathrm{SR}$ and SS clays had similar behavior, while the EC clay had a higher liquid limit value, due probably to the high amount of smectite clay mineral.

Table IV - Liquid limit (LL), plastic limit (PL) and plasticity index (PI) of the studied clays.

[Tabela IV - Limite de liquidez (LL), limite de plasticidade $(L P)$ e indice de plasticidade (IP) das argilas estudadas.]

\begin{tabular}{cccc}
\hline Clay & LL $(\%)$ & PL $(\%)$ & PI $(\%)$ \\
\hline EC & 48.0 & 31.8 & 16.2 \\
LB & 31.2 & 17.7 & 13.6 \\
MC & 31.3 & 21.5 & 9.9 \\
SR & 32.9 & 19.1 & 13.8 \\
SS & 35.3 & 22.8 & 12.5 \\
ST & 21.8 & 10.3 & 11.5 \\
\hline
\end{tabular}

In order to evaluate the strength of the studied clays and, consequently, their contribution to the mechanical strength of the green body, the green strength of the samples was determined as a function of the amount of pressing water. Fig. 4 shows the range of the modulus of rupture (MOR) of green compacts as a function of pressing water content. The reference clay had a maximum MOR value of 2.5 $\mathrm{MPa}$, while samples LB, SR and MC displayed higher values of strength. This was related to the combination of packing, clay content and organic matter in these samples that allowed them to achieve higher strength values. This is interesting from a commercial point of view since it indicates that the use of theses clays cannot damage the strength of the produced green body. The mechanical strength values of LB, SR, SS, and MC clays were close to those of Ukrainian ball clays [10] at 8\% moisture content,

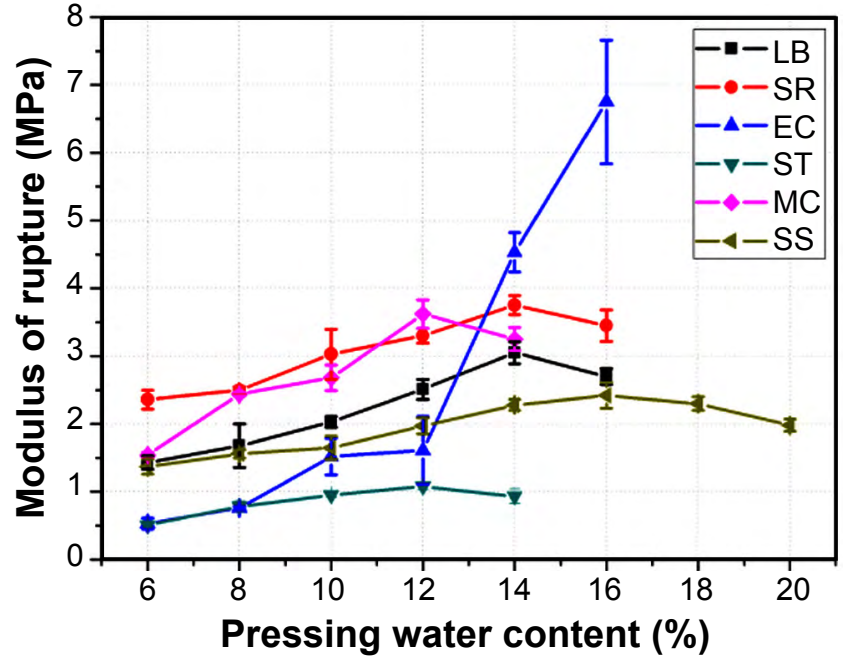

Figure 4: Modulus of rupture (MOR) of green clay bodies as a function of pressing water content.

[Figura 4: Módulo de ruptura à verde em função do percentual de água de prensagem.]

with values ranging from 1.5 to $2.5 \mathrm{MPa}$. Depending on the particle size of the clay, dry strength values for ball clays reported in the literature [6] range from 0.2 to $5 \mathrm{MPa}$. The dry strength of ball clays is greater than their green strength, but it can be observed that the obtained green values were in the range presented in literature for ball clays. Similar to what was observed on the results of plasticity test, the strength behavior of ST and EC samples differed from the other clays. Sample ST had strength values lower than the others and the EC sample showed a high strength with $14 \%$ of water content. These behaviors were attributed to the high quartz amount of ST and the presence of high level of smectite clay mineral in EC sample.

Ball clays are used in the production of sanitary ware and porcelain stoneware and tile and have an important influence on shaping process, drying, firing stage, and final properties. However, their successful use is dependent on their mineralogy, particle size, organic matter amount and surface activity characteristics. Mineralogy is intimately related to several characteristics of ball clays, such as the color after firing. A characteristic commonly required for ball clays is the presence of low amount of coloring oxides, such as $\mathrm{Fe}_{2} \mathrm{O}_{3}$ and $\mathrm{TiO}_{2}$. Literature indicates that clays used in porcelain tile formulations should have $\mathrm{Fe}_{2} \mathrm{O}_{3}<1 \%$ [6, 29], however a limit of $3 \%$ of $\mathrm{Fe}_{2} \mathrm{O}_{3}$ in ball clays used for the production of light-firing bodies, such as sanitary ware, is overall accepted [19]. High amount of $\mathrm{Fe}_{2} \mathrm{O}_{3}$ can cause ceramic body deformation [30], incorporation of iron ions in the glassy phase and/or in the crystalline phases, and the development of dark-firing bodies. Clays EC, MC and SR present amounts of iron oxide higher than 3\% (Table V), which was related to the presence of smectite and illite clay minerals in these clays. Conventional ball clays contain up to $0.4 \%-0.5 \%$ of organic matter $[18,19]$, and high plastic clays can present amounts of organic matter higher than $3 \%$ [18]. However, due to the scarcity of high-quality 
Table V - Analysis of the potential use of studied clays for porcelain and sanitary ware ceramics.

[Tabela $V$ - Análise do potencial das argilas estudadas para uso em porcelanas e cerâmicas sanitárias.]

\begin{tabular}{lccccccc}
\hline Characteristic & Reference $^{\mathrm{a}}$ & $\mathrm{EC}$ & $\mathrm{LB}$ & $\mathrm{MC}$ & $\mathrm{SR}$ & $\mathrm{SS}$ & $\mathrm{ST}$ \\
\hline Iron oxide content $(\mathrm{w} / \mathrm{w})$ & $<3.0 \%$ & - & $\mathrm{x}$ & - & - & $\mathrm{x}$ & $\mathrm{x}$ \\
Loss on ignition $(\mathrm{w} / \mathrm{w})$ & $>8 \%$ & $\mathrm{x}$ & $\mathrm{x}$ & $\mathrm{x}$ & $\mathrm{x}$ & $\mathrm{x}$ & - \\
Mass loss $200-400{ }^{\circ} \mathrm{C}$ (organic matter, $\left.\mathrm{w} / \mathrm{w}\right)$ & $<2.0 \%$ & $\mathrm{x}$ & $\mathrm{x}$ & $\mathrm{x}$ & $\mathrm{x}$ & $\mathrm{x}$ & $\mathrm{x}$ \\
Amount of smectite type mineral $(\mathrm{w} / \mathrm{w})$ & $<5 \%$ & 28.1 & - & - & 2.0 & - & - \\
Particle equivalent diameter $<2 \mu \mathrm{m}$ & $>40 \%$ & - & $\mathrm{x}$ & - & - & $\mathrm{x}$ & $\mathrm{x}$ \\
Plasticity index & $>12 \%$ & $\mathrm{x}$ & $\mathrm{x}$ & - & $\mathrm{x}$ & $\mathrm{x}$ & - \\
Modulus of rupture of green body $(\mathrm{MPa})$ & $>1.5$ & $\mathrm{x}$ & $\mathrm{x}$ & $\mathrm{x}$ & $\mathrm{x}$ & $\mathrm{x}$ & - \\
Analysis & Porcelain & No & Good & No & No & Good & Good \\
& Sanitary ware & No & Good & No & Good & Good & No \\
\hline
\end{tabular}

a - according to literature data $[6,10,11,18,19,21]$.

clays, plastic clays with organic matter up to $2 \%$ have been used in production of sanitary ware and porcelain bodies [21]. The loss of mass in the range of 200 to 400 ${ }^{\circ} \mathrm{C}$ and LOI were indicatives of the organic matter present in the studied clays (Table V). All samples presented values of organic matter in the range that could be used as alternative ball clays. The properties of ball clays also depend on the content of clay minerals. High-quality ball clays contain high amounts of low-ordered kaolinite [9] and small amounts of illite and fine quartz. However, some amounts of smectite minerals are generally present in ball clays. Small amounts of montmorillonite increase the green strength and the plasticity, however, also raise the firing shrinkage and the amount of iron, and affects the deflocculation behavior of the clay $[6,18,21]$. Amounts of smectite clay minerals lower than $5 \%$ in the ball clay are required, but good quality ball clays cannot have amounts higher than $2 \%$. Thus, clay EC cannot be used for the production of porcelain or sanitary ware and SR could be used as ball clay depending on its other characteristics.

The plasticity of the clay is an indication of its particle size, mineralogical composition [1], colloidal fraction of particles and presence of organic matter [6]. High-quality ball clay presents clay fraction over $75 \%[10,19]$, but commercial clays used as ball clays nowadays present clay fractions over $40 \%$. LB and ST clays presented the higher clay fractions among the studied clays, but the ST clay did not present high plasticity. This was related to the high amount of quartz and low amount of organic matter on this clay. The other clays presented plasticity index higher than 12, which was lower than the lower limit of 19 indicated in literature data [19] for good quality ball clays, but indicated a good plastic behavior and potential use as alternative ball clay. However, the higher value of plasticity index of clay EC was related to its high amount of smectite clay mineral and was a negative point for the use of this clay as alternative ball clay. The green strength property is very important in most type of claybased bodies because they need to be handled during the processing. The strength depends on the amount of clay fraction, presence of organic matter and mineralogical composition, and is related to plasticity behavior of the clay. Ball clays present green strength higher than 1.5 MPa [10], while high plastic clays have green strength higher than $10 \mathrm{MPa}$ [18]. However literature data [10] also indicates values of green strength of $1 \mathrm{MPa}$ for conventional ball clays. Clays EC, LB, MC, and SR presented values of modulus of rupture higher than 1.5 MPa. Results indicated that that EC sample is not suitable for use as alternative ball clays for porcelain or sanitary ware because of its high content of smectite, while the MC clay is not adequate due to the high amount coloring oxide and low plasticity. LB and ST clays had characteristics (Table V) that make them potential alternative ball clays for the production of porcelain bodies, considering the lower limit for the green strength of $1 \mathrm{MPa}$. LB and SR are potential alternative ball clays for the production of sanitary ware considering their overall characteristics (Table V). However, the high amount of coloring oxide and low clay fraction of SR may be a limiting factor to its use in certain formulations for sanitary ware.

\section{CONCLUSIONS}

The studied plastic clays from Northeastern Brazil had silica and/or iron oxide content higher and organic matter content lower than those of the reference São Simão ball clay. Some of the clays had smectite clay mineral or high amount of quartz, which are not desirable for sanitary ware production. The particle size distributions of the studied clays were, however, close to that of the reference São Simão clay. Three of the studied clays had plasticity characteristics similar to those of the reference ball clay and higher green strength. According to characterization data, three alternative plastic clays (Lambedor, Sítio, and Santa Rita) had plasticity and mineralogical characteristics similar to those of the reference ball clay and have potential to be used as alternative ball clays. 


\section{ACKNOWLEDGMENTS}

The authors would like to thank the Brazilian research funding agency $\mathrm{CNPq}$ (National Council for Science and Technology), grant No. 310932/2015-7, CAPES for their financial support, and the companies Armil Mineração do Nordeste, Caulisa, Icra Produtos para Cerâmica , DuratexPE, Luzarte Estrela, Cerâmica Mari and Gesso Chaves for the supply of materials.

\section{REFERENCES}

[1] M. Dondi, C. Iglesias, E. Dominguez, G. Guarini, M. Raimondo, Appl. Clay Sci. 40 (2008) 143.

[2] N.N. Staneva, I.H.K. Asabov, H.A. Lonchev, Ceram. Int. 21 (1995) 119.

[3] M.S. Eygi, G. Ateşok, Ceram. Int. 34 (2008) 1903.

[4] A. Bernasconi, N. Marinoni, A. Pavese, F. Francescon, K. Young, Ceram. Int. 40 (2014) 6389.

[5] R.H.L. Silva, G.A. Neves, H.C. Ferreira, L.N.L. Santana, A.C.V. Nóbrega, R.R. Menezes, Cerâmica 65, 373 (2019) 1. [6] H.H. Murray, Applied clay mineralogy: occurrences, processing and application of kaolins, bentonites, palygorskite-sepiolite, and common clays, Elsevier (2007).

[7] J.F. Burst, R.E. Hughes, in Construction uses: clay based ceramic raw materials, D.D. Carr (Ed.), $6^{\text {th }}$ ed., Soc. Min. Metal. Explor., Littleton (1994) 317.

[8] F. Andreola, C. Siligardi, T. Manfredini, C. Carbonchi, Ceram. Int. 35 (2009) 1159.

[9] K. Galos, Appl. Clay Sci. 51 (2011) 74.

[10] C. Zanelli, C. Iglesias, E. Domínguez, D. Gardini, M. Raimondo, G. Guarini, M. Dondi, Appl. Clay Sci. 108 (2015) 102.

[11] Y. Lin, L.K.-J. Cheah, N. Phan-Thien, B.C. Khoo, Colloids Surf. A 506 (2016) 1.

[12] R.T. da Cruz, C.P. Bergmann, S.R. Bragança, Cerâmica 58, 345 (2012) 66.

[13] E. Martini, D. Fortuna, A. Fortuna, G. Rubino, V.
Tagliaferri, Cerâmica 63, 368 (2017) 542.

[14] M. Tarhan, B. Tarhan, T. Aydin, Ceram. Int. 42 (2016) 17110.

[15] E. Becker, J.Jiusti, F.D. Minatto, D.G.G. Delavi, O.R.K. Montedo, A. de Noni Jr., Cerâmica 63, 367 (2017) 295.

[16] B. Ronald, Am. Sci. Res. J. Eng. Technol. Sci. 42 (2018).

[17] V.C. Nwachukwu, S.A. Lawal, IOP Conf. Ser. Mater. Sci. Eng. 413 (2018) 12076.

[18] I.R. Wilson, Cerâmica 44, 287-288 (1998) 88.

[19] M. Dondi, M. Raimondo, C. Zanelli, Appl. Clay Sci. 96 (2014) 91

[20] R.L. Virta, Min. Eng. 66 (2014) 35.

[21] R.R. Menezes, G.A. Neves, H.S. Ferreira, Rev. Eletr. Mater. Proc. 9 (2014) 118.

[22] E. Kamseu, C. Leonelli, D.N. Boccaccini, P. Veronesi, P. Miselli, G. Pellacani, U.C. Melo, Ceram. Int. 33 (2007) 851.

[23] J.M. Cartaxo, P. de M. Bastos, L.N.L. Santana, R.R. Menezes, G.A. Neves, H.C. Ferreira, Cerâmica 62, 364 (2016) 338.

[24] M. Link, S.R. Bragança, C.P. Bergmann, Cerâm. Ind. 18 (2013) 25.

[25] R.E. Grim, Applied clay mineralogy, McGraw-Hill, New Work (1962).

[26] W.H. Fitzjohn, W.E. Worrall, Trans. J. Br. Ceram. Soc. 79, 3 (1980) 74.

[27] F. Ginés, C. Feliu, J. García-Ten, V. Sanz, Bol. Soc. Esp. Ceram. V. 36 (1997) 25.

[28] M. Raimondo, M. Cocchi, G. Dircetti, M. Dondi, A. Ulrici, P. Zannini, in Proc. $12^{\text {th }}$ Int. Clay Conf., Bahía Blanca, Elsevier (2003) 301.

[29] E. Barrachina, I. Calvet, D. Fraga, J.B. Carda, Appl. Clay Sci. 143 (2017) 258.

[30] F. Jiang, Y. Li, L. Zhao, D. Cang, Appl. Clay Sci. 143 (2017) 199.

(Rec.23/08/2018, Rev.28/01/2019, 25/03/2019, 19/04/2019, Ac. 15/05/2019) 